Am. J. Trop. Med. Hyg., 32(1), 1983, pp. 146-153

Copyright 1983 by The American Society of Tropical Medicine and Hygiene

\title{
DIARRHEA ASSOCIATED WITH ROTAVIRUSES, ENTEROTOXIGENIC ESCHERICHIA COLI, CAMPYLOBACTER, AND OTHER AGENTS IN COSTA RICAN CHILDREN, 1976-1981*
}

\author{
LEONARDO MATA, ALBERTO SIMHON, ROBERTO PADILLA, MARÍA DEL MAR GAMBOA, \\ GUILLERMO VARGAS, FRANCISCO HERNÁNDEZ, EDGAR MOHS, AND CECILIA LIZANO \\ Instituto de Investigaciones en Salud (INISA), Universidad de Costa Rica, Ministerio de Salud, \\ and Hospital Nactonal de Niños, San José, Costa Rica
}

\begin{abstract}
Rotaviruses, enterotoxigenic Escherichia coli, Salmonella, Shigella, and parasites were investigated in outpatient diarrheic children, and in hospitalized diarrheic and nondiarrheic children, between January 1976 and June 1979. In outpatient cases studied within 4 days of onset of symptoms, rotaviruses were the most common agen's $(45.3 \%)$; $E$. coli heatstable enterotoxin ranked second (13.4\%); Shigella was thirc $(8.1 \%)$; Salmonella was fourth $(7.3 \%)$. In $63.2 \%$, one or more enteric agents were detected. In hospitalized non-diarrheic children, asymptomatic shedding of pathogens was rarely observed. A later survey of outpatient diarrheic children revealed Campylobacter fetus jejuni in $8 \%$. In 5.5 years of observation rotaviruses were endemic with excess frequency in the dry and cooler months of December and January. The excess occurrence of bacterial pathogens did not coincide with that of rotaviruses.
\end{abstract}

Costa Rica has experienced a dramatic improvement in the quality of life, particularly in the last 2 decades. Potable water and latrinization have become a reality for nearly a $100 \%$ of the urban and for over 70\% of the rural population. Per capita income in 1980 ranked third in Latin America. Comprehensive rural health programs coupled with social and economic measures ${ }^{1,2}$ have resulted in a drastic reduction in diarrhea deaths from over 400 in the 1920 s to 5 per 100,000 in $1980 .^{3}$ Infant mortality-highly correlated with diarrheal disease mortality-declined abruptly from 200 to 19 per 1,000 live births in the same period. ${ }^{3}$ Nevertheless, diarrheal disease remains a leading cause of morbidity and a relatively important cause of death in Costa Rican children. In 1976, a prospective study by the Instituto de Investigaciones en Salud (INISA) in collaboration with the National Children's Hospital in San José, Capital City of Costa Rica was begun. One aim was to identify newly recognized agents of diarrhea, e.g., rotaviruses and enterotoxigenic bacteria, in addition to the classical salmonellae, shigellae and intestinal protozoa. Clinical and

Accepted 10 June 1982.

* Address reprint requests to: Dr. L. Mata, INISA, University of Costa Rica, San José, Costa Rica. epidemiological data were collected from 19761979. Furthermore, a survey was made in 1980 and 1981 to identify Campylobacter fetus jejuni and rotaviruses in children of the same hospital.

\section{MATERIALS AND METHODS}

From January 1976 to June 1981, 888 diarrheic children, seen Mondays through Wednesdays as outpatients at the Emergency Ward of the National Children's Hospital, were included in the study. From 10-20 cases were studied per month. Larger numbers were studied during epidemics. Children were less than 24 months old and fecal specimens were.obtained within a few hours of registration at the hospital. Patients with dehydration were treated with intravenous electrolyte solutions during 1976-1977; in 1978 oral rehydration was prescribed in about $90 \%$ of children, and rapid intravenous therapy in the rest. Of the 888 cases, 655 were studied from January 1976 to June 1979, providing seasonal data on rotaviruses; of these, 496 children studied from January 1976 to April 1978 were also investigated for enterotoxigenic Escherichia coli (ETEC), Shigella, Salmonelle and parasites. Relative frequencies were analyzed against mean rainfall, wind velocity, and humidity. The remaining 233 cases were studied from December 1980 to June 1981, only for frequency rate of rotaviruses and Campylobacter fetus jejuni. Collateral to the study of outpatients, 
167 hospitalized diarrheic children less than 2 years of age, and 215 non-diarrheic controls of the same and hospital ward were studied. These children were investigated within 48 hours of hospitalization during 1976 1978 in order to assess pathogenic significance of the agents. Patients were mainly from the Intermountain Central Valley (mean elevation 1,000 meters) where $75 \%$ of the country's 2.3 million population live. Most children came from families of lower and lower-middle socioeconomic status.

Fresh feces were inoculated onto tergitol-7 with $0.04 \%$ triphenyl tetrazolium chloride, ${ }^{4} \mathrm{Sal}$ monella-Shigella and McConkey agars; suspected colonies were transferred to lysine-iron and triple sugar-iron slants; presumptive colonies of salmonellae and shigellae were identified by standard biochemical and serological technics, ${ }^{3}$ using commercial antisera (Difco, BBL).

For the study of Escherichia coli heat-labile enterotoxin (LT), 10 typical colonies were pooled and cultured in $5 \mathrm{ml}$ casaminoacids-yeast extract broth, shaken at $140 \mathrm{cycles} / \mathrm{min}$ in $50 \mathrm{ml}$ flasks for 18 hours at $37^{\circ} \mathrm{C}$; bacterial growth was treated with polymyxin $B$, they were shaken again for $15 \mathrm{~min}$, and centrifugated at $16,000 \times \mathrm{g}$ at $4^{\circ} \mathrm{C}$ for $20 \mathrm{~min}$. The supernatants were stored at $-70^{\circ} \mathrm{C}$ until tested for LT. Initially, extracts were tested by the passive immunohemolysis test. ${ }^{6}$ However, after blind comparison of 545 extracts by the passive immunohemolysis test and the enzyme-linked immunosorbent assay (ELISA), ${ }^{7}$ the latter technic was chosen in view of its comparable sensitivity ${ }^{\mathrm{B}}$ and ease of operation. Thus, all extracts were tested for LT by the ELISA.

To test for $E$. coli heat-stable toxin (ST), preparations were made by inoculating 10 typical colonies in $10 \mathrm{ml}$ of brain heart infusion broth, shaking at $120 \mathrm{cycles} / \mathrm{min}$ in $125 \mathrm{ml}$ Erlenmeyer fiasks for 24 hours at $37^{\circ} \mathrm{C}$, and centrifugating at $1,200 \times \mathrm{g}$ for $30 \mathrm{~min}$; the supernatants were filtered through $0.45 \mu \mathrm{m}$ Millipore membranes and $3 \mathrm{ml}$ of filtrates were transferred to sterile vials containing $0.2 \mathrm{ml}$ of sterile glycerin, and stored at $-70^{\circ} \mathrm{C}$. All extracts were assayed in infant mice, using per os inoculation. ${ }^{9}$

Extracts from strains H-1040 and K-12 were used as positive and negative controls, respectively, in all assays for LT and ST toxins.

For isolation of $C$. fetus jejuni, feces were inoculated onto Butzler's thyoglycolate agar plates containing $15 \%$ sheep blood and antibiotics; ${ }^{10}$ plates were incubated in jars with GAS-PAK gen- erators but devoid of catalyst, at $42^{\circ} \mathrm{C}$ for 48 hours. Presumptive isolates were examined microscopically for typical motility, and for oxidase, catalase, nitrate reduction and fermentation reactions. "11

For the study of rotaviruses, $10-20 \%$ fecal suspensions were prepared in brain heart infusion broth containing $0.5 \%$ bovine serum albumin; suspensions were frozen at $-70^{\circ} \mathrm{C}$ until tested. The clarified extracts of the first year of the study (1976) were examined by transmission electron microscopy (TEM) using formvar coated grids, ${ }^{12}$ and the results of the technic adapted to local conditions ${ }^{13}$ were compared with those obtained with the ELISA $^{14,15}$ done with goat and guinea pig hyperimmune sera to human rotavirus. Since the sensitivity and ease of operation of the ELISA was superior, ${ }^{16}$ all specimens were assayed for rotavirus antigen by the ELISA. All presumptive positives were confirmed by blocking-tests using convalescent calf serum. ${ }^{17}$

For investigation of parasites, a direct microscopic examination of fresh feces was made by mixing fecal material with physiologic saline; coccidia were not especially investigated. For eggs and cysts, an ether-formalin concentration was performed. ${ }^{18}$ Occult blood was directly assessed by the benzidine reagent. A fecal smear was fixed and treated with Wright's stain for study of leukocytes, erythrocytes, macrophages, and other cellular elements.

\section{RESULTS}

In order to assess frequency rates of infectious agents, only those children examined within four days of onset of diarrhea were considered suitable. Of the 655 outpatients 345 met that restriction and were selected for the analysis (Table 1). In $63.2 \%$, one or more enteric agents were detected. Rotaviruses were the most $(34.5 \%$ "pure" plus $10.8 \%$ mixed infections), followed by ETEC ST ( $9 \%$ "pure" plus $4.4 \%$ mixed infections), by Shigella (8.1\%), and Salmonella (7.3\%). Double infections were found in $11 \%$ of children, with rotaviruses nearly always present.

By means of a computer program, all cases positive for only one of the five etiologies investigated, a total of 230 , were separated for an analysis by age (Table 2). This is a larger series than the 179 cases with a single pathogen shown in Table 1 because the restriction of duration of diarthea was removed. The distribution of the 230 cases 
Table 1

Single and multiple infections, 345 Emergency Ward outpatients with diarriea, National Childrex's Hospital, Costa Rica, 1976-1979

\begin{tabular}{|c|c|c|c|}
\hline Infection with & Number & $\%$ & $\begin{array}{c}\text { Cummur- } \\
\text { lative } \\
\text { to }\end{array}$ \\
\hline One agent & 179 & 51.9 & 51.9 \\
\hline Two agents & 38 & 11.0 & 62.9 \\
\hline Three agents & 1 & 0.3 & 63.2 \\
\hline None detected & 127 & 36.8 & 100.0 \\
\hline Rotavirus only & 119 & 34.5 & 34.5 \\
\hline E. coll ST only & 31 & 9.0 & 43.5 \\
\hline Shigella only & 15 & 4.3 & 47.8 \\
\hline Salmonella only & 14 & 4.1 & 51.9 \\
\hline Rotavirus \& $E$. coli ST & 13 & 3.8 & 55.7 \\
\hline Rotavirus \& Salmonalla & 11 & 3.2 & 58.9 \\
\hline Rotavirus \& Shigella & 10 & 2.9 & 61.8 \\
\hline Rotavirus \& $E$. coli LT & 2 & 0.6 & 62.4 \\
\hline Shigella \& $\mathrm{E}$. colf $\mathbf{L T}$ & 1 & 0.3 & 62.7 \\
\hline Shigelle \& E. coli ST & 1 & 0.3 & 63.0 \\
\hline \multicolumn{4}{|l|}{ Rotavirus, Shigallo \& } \\
\hline E. coli ST & 1 & 0.3 & 63.3 \\
\hline
\end{tabular}

- 44 days of envet; <24 monthe of age.

showed that $87 \%$ were infants. ETEC, Shigella and Salmonello were virtually absent in children older than 1 year, contrasting with rotaviruses which were diagnosed in about $20 \%$ in the 2 nd year of life.

More than $80 \%$ of "pure" rotavirus and ETEC ST cases were seen in the Emergency Ward within 4 days of onset of symptoms (Table 3 ). Information on this variable was not available for three cases contained in Table 2 . One third of children with Shigella and Salmonella were brought to the hospital at a later date.

In order to establish differences in relative frequency of the agents investigated with regard to the presence or absence of diarrhea, a comparison was made of 167 hospitalized diarrheic and 215 hospitalized non-diartheic controls (Table 4). While

Tamle 2

Distribution by age, 230 "pure specific diarrhea" outpatients, * National Children's Hospital, 1976-1979

\begin{tabular}{ccccc}
\hline $\begin{array}{c}\text { Age, } \\
\text { months }\end{array}$ & $\begin{array}{c}\text { Rotavirus } \\
\mathbf{N}=146\end{array}$ & $\begin{array}{c}E T E C_{,}, 5 T \\
\mathbf{N}=39\end{array}$ & $\begin{array}{c}\text { Shigella } \\
\mathbf{N}=23\end{array}$ & $\begin{array}{c}\text { Salmomella } \\
\mathbf{N}=22\end{array}$ \\
\hline $0-5$ & $58(39.7) \dagger$ & $24(61.5)$ & $14(60.9)$ & $17(77.3)$ \\
$6-11$ & $59(40.4)$ & $15(38.5)$ & $8(34.8)$ & $5(22.7)$ \\
$12-17$ & $24(16.4)$ & 0 & 0 & 0 \\
$18-23$ & $5(3.4)$ & 0 & $1(4.3)$ & 0 \\
\hline
\end{tabular}

- No apure" cuts of ETFC, LT wete found; Camplobacter, Atromo

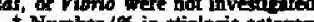

TABLE 3

Days with diarrhed when specimen taken, 227 outpetients $<2$ years-ald, positive for only one of five possible agents, * National Children's Hospital, 1976-1979

\begin{tabular}{|c|c|c|c|c|}
\hline $\begin{array}{c}\text { Days } \\
\text { whib } \\
\text { dienthea }\end{array}$ & $\begin{array}{l}\text { Rotavinus } \\
N=145\end{array}$ & $\begin{array}{l}E T E C, ~ s T \\
\mathbf{N}=37\end{array}$ & $\begin{array}{l}\text { Shiretla } \\
N=23\end{array}$ & $\begin{array}{l}\text { Salmonetla } \\
\mathrm{N}=22\end{array}$ \\
\hline$<1$ & $35(24.1) \dagger$ & $5(13.5)$ & $2(8.7)$ & $2(9.1)$ \\
\hline 2 & $27(18.6)$ & $8(21.6)$ & $3(13.0)$ & $4(18.2)$ \\
\hline 3 & $38(26.2)$ & $11(31.4)$ & $3(13.0)$ & $3(13.6)$ \\
\hline 4 & $20(13.8)$ & $8(21.6)$ & $7(30.4)$ & $5(22.7)$ \\
\hline 5 & $4(2.7)$ & 0 & $3(13.0)$ & $5(22.7)$ \\
\hline 6 & $5(3.4)$ & $2(5.4)$ & $1(4.3)$ & 0 \\
\hline 7 & $1(0.7)$ & $1(2.7)$ & $1(4.3)$ & D \\
\hline $8-15$ & $12(8.2)$ & $2(5.4)$ & $3(13.0)$ & $3(13.6)$ \\
\hline $16-30$ & $3(2.1)$ & 0 & 0 & 0 \\
\hline
\end{tabular}

- No "pure" cases of ETBC, LT were found; Cemplobecier, deromo nit, and Vibrio were not invertigated.

+ Number (\%).

asymptomatic excretion was demonstrated for all agents studied, significant differences were detected in the frequencies of pathogens in diarrheic and non-diarrheic children.

In "pure specific diarrheas," that is, those with only one of the five etiologies investigated, respiratory symptoms were not found in excess in rotavirus diarrhea as compared to the others (Table 5). This analysis was made in $\mathbf{1 7 4}$ children out of the 179 pure diarrheas (Table 1); 5 cases with ETEC ST had incomplete clinical records and were excluded. Vomiting was more frequent with rotavirus and ETEC ST than with Salmonella diarrhea. About $10 \%$ of rotavirus diarrhea cases were dehydrated upon admission. Leukocytes, erythrocytes and macrophages were very common in Shigella diarrhea, but were rarely found in pure rotavirus infections. Occult blood was detected in more than $80 \%$ of shigellosis and salmonellosis.

Protozoans and nematodes were found in $4.9 \%$ of 511 outpatient diarrheic children in whom parasites could be investigated; Giardia lamblia accounted for most of these. One case each of Strongyloides stercoralis and Trichuris trichiura were found; no cases of Entamoeba histolytica were discovered.

In the 5.5 years of observation, rotaviruses constantly occurred in endemic and epidemic situations. In the cooler months (December and January) frequencies ranged between 50 and $90 \%$. In endemic periods, rates were around $20-30 \%$. Months of excessive rotavirus diarrhea were December 1976; January, July, August, and December 1977; October and November 1978; December 1980; and January 1981. No data were available 
TABLE 4

Frequency of infection, hospitalized children with diamhea and without diarhea from three hospital wards, National Children's Hospital, $1976-1979$

\begin{tabular}{cccccc}
\hline Diarrhea & Rotavirus & ETEC, ST & ETEC, LT & Shigella & Salmonella \\
\hline Yes & $32(19.2)^{*}$ & $29(19.2)$ & $16(9.6)$ & $12(7.2)$ & $17(10.2)$ \\
& $\mathrm{N}=167$ & $\mathrm{~N}=151$ & $\mathrm{~N}=166$ & $\mathrm{~N}=167$ & $\mathrm{~N}=167$ \\
No & $2(0.9)$ & $3(2.0)$ & $\mathrm{N}(3.1)$ & $1(0.5)$ & $6(2.8)$ \\
& $\mathrm{N}=214$ & $\mathrm{~N}=151$ & $\mathrm{~N}=159$ & $\mathrm{~N}=215$ & $\mathbf{N}=215$ \\
$x^{2}$ & 36.13 & 21.85 & 4.64 & $<0.95$ & 7.81 \\
$P$ & $<0.001$ & $<0.001$ & $<0.05$ & $<0.001$ & $<0.01$ \\
\hline
\end{tabular}

* Number of positives ( $\%$ ); $\mathbf{N}=$ number of cases in which etiolegic agent was investigated.

for July 1979-November 1980, months of low diarrhea morbidity. The explosive character of rotavirus epidemics was evident in late 1976 and early 1977 in which the largest outbreak occurred, with rapid sfoding of communities in the Intermountain Central Valley. To illustrate, most cases of acute rotavirus diarrhea diagnosed in December 1976-February 1977 corresponded to $18 \mathrm{mu}-$ nicipalities of the 80 in the total territory. Since about $20 \%$ of these came from outside the catchment area of the hospital, it is expected that the outbreak covered most of the Costa Rican territory within that short period.

The frequency rate of bacteria (the sum of ETEC ST and LT, Salmonella and Shigella) also showed epidemic peaks, but these generally did not coincide with those of rotavirus (Fig. 1). When this study was started, the methodology for cultivation of Campylobacter had not been implemented in Costa Rica. In order to gauge the importance of this agent, a survey was conducted in 233 emergency ward outpatients from December 1980 through June 1981 for the presence of $C$. fetus jejuni and of rotaviruses. Campylobacter appeared singly ot in double infections throughout the study period in $8 \%$ of the children; in June, a rainy and warm month, the frequency increased to $23 \%$ (Table 6, Fig. 1). In the warmer months of April through June no mixed infections with rotaviruses were seen, and the rate of Campylobacter remained high while that of rotaviruses decreased. The overall rotavirus frequency in this survey was comparable to that described earlier for the period 1976-1979.

Monthly data on rainfall, temperature (maximum, median, and minimum), wind velocity, and relative humidity were available for the Intermountain Central Valley, from which most of the diarrhea cases came. No significant correlation was observed between rotavirus frequency rates versus temperature and wind velocity during 29 months in which complete monthly data on paired variables were available. However, a significant negative correlation was obtained between frequency of rotavirus and rain precipitation $(r=$ $-0.46 ; P<0.05$ ) and between frequency of rotavirus and relative humidity $(r=-0.44 ; P<$ $0.05)$.

\section{DISCUSSION}

Rotaviruses have been implicated as the most prominent agents of diarrheal disease, and as the main contributors to morbidity and mortality among infants and young children throughout the world. ${ }^{19}$ In Costa Rica, rotaviruses were associ-

Table 5

Clinical features, 174 outpatients with diawhea, positive for only one of five possible agents, * Emargency Ward, National Children's Hospilal, 1976-1979

\begin{tabular}{|c|c|c|c|c|}
\hline & $\begin{array}{l}\text { Rotuvints } \\
\mathbf{N}=119\end{array}$ & $\begin{array}{c}\text { ETEC, ST } \\
\mathrm{N}=26\end{array}$ & $\begin{array}{l}\text { Shigello } \\
\mathbf{N}=15\end{array}$ & $\begin{array}{c}\text { Salmomella } \\
\mathrm{N}=14\end{array}$ \\
\hline Respiratory symptoms & $15(13) \dagger$ & 0 & $2(13)$ & $2(14)$ \\
\hline Vomiting & $91(77)$ & $18(72)$ & $10(67)$ & $6(43)$ \\
\hline Fever $\left(>37.5^{\circ} \mathrm{C}\right)$ & $80(67)$ & $10(38)$ & $7(47)$ & $9(64)$ \\
\hline
\end{tabular}

"No "pure" cases of ETEC, LT were found Campylobacter, deromonas, and Vibrio were not investigated.

$t$ Number of positive cases $(\%)$. 


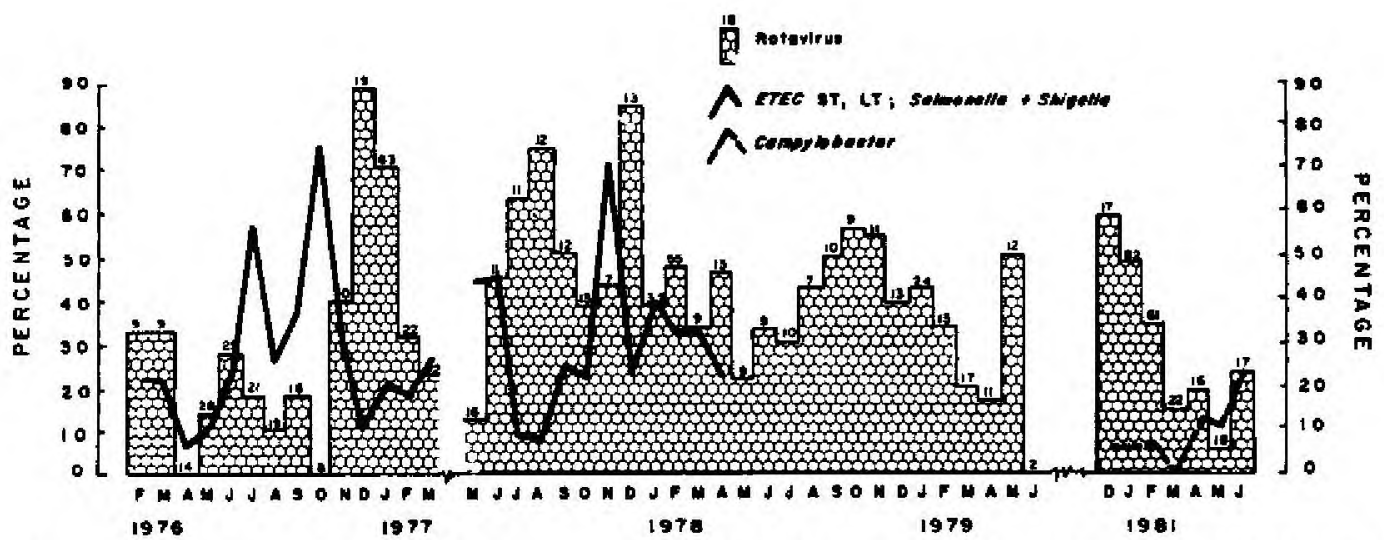

FiguRE 1. Monthly prevalence of rotaviruses and enteric pathogenic bacteria among children under 2 years of age with acute diarrheal disease, examined at the outpatient Emergency Ward, National Children's Hospital, Costa Rica, 1976-1981. Numbers on top of bars indicate cases studied.

ated with more than $40 \%$ of all diarrhea cases, singly or mixed with bacteria, during 5.5 years of surveillance of diarrheic children admitted to the Emergency Ward of the National Children's Hospital. The rate was similar to that obtained by others in developing countries. ${ }^{20-21}$ In Mexico, a lower frequency of rotaviruses was noted, ${ }^{22-24}$ but the rate of multiple infections was near $24 \%$ in one study; in Costa Rica, multiple infections were one half of that figure.

ETEC ST was found in $13 \%$ of all diarrheic children, but ETEC LT occurred in less than $2 \%$. This contrasts with reports from Mexico and Bangladesh, where ETEC strains were found in $47 \%$ and $28 \%$, respectively. ${ }^{21,23}$ In both populations, ST toxin-producers predominated, and many strains produced both toxins. In Costa Rican diarrheic children, virtually all isolates were ST-producers. No ST/LT producing strains were found, whereas $7 \%$ of Bangladeshi children shed strains producing both toxins."

Salmonella and Shigella had a combined frequency of $15.4 \%$ including single and double infections, a rate in excess of that observed in Bangladesh but below the Mexican figure (5\% and $26 \%$, respectively). Due to the lability and the relatively low number of Shigella bacilli in feces, the present rate is likely to be an underestimate. Serial specimens would probably have yielded more shigellae in the Costa Rican children.

In developing nations the relative frequency of Campylobacter isolates in diarrheic children and

TABLE 6

Rotovirus and Campylobacter fetus jejuni, * Emergency Ward outpatients, National Children's Hospital, December $1980-J u n e$ 1981

\begin{tabular}{|c|c|c|c|c|c|c|c|}
\hline & \multirow[b]{2}{*}{ Cases } & \multicolumn{6}{|c|}{ Number positive (\%) } \\
\hline & & $\begin{array}{l}\text { Rotavirus } \\
\text { only }\end{array}$ & $\begin{array}{l}\text { C. } f . j e j u n i \\
\text { only }\end{array}$ & $\begin{array}{c}\text { Rotavirus } \\
+ \\
\text { C. }{ }^{\prime} \text { jojuni }\end{array}$ & $\begin{array}{l}\text { Total with } \\
\text { rotavirus }\end{array}$ & $\begin{array}{l}\text { Total with } \\
c . f . \text { jejwri }\end{array}$ & $\begin{array}{l}\text { Rotavirus } \\
\text { andlor } \\
\text { c. } f . \text { jejuni }\end{array}$ \\
\hline December & 17 & $9(53)$ & 0 & 1 & $10(59)$ & $1(6)$ & $10(59)$ \\
\hline January & 82 & $36(44)$ & 2 & 3 & $39(48)$ & $5(6)$ & $41(50)$ \\
\hline February & 61 & $18(29)$ & 1 & 3 & $21(34)$ & $4(7)$ & $22(36)$ \\
\hline March & 22 & $3(14)$ & 0 & 0 & $3(14)$ & 0 & 3 (14) \\
\hline April & 16 & $3(19)$ & 2 & 0 & $3(19)$ & $2(12)$ & $5(31)$ \\
\hline May & 18 & $1(5)$ & 2 & 0 & $1(6)$ & $2(11)$ & $3(17)$ \\
\hline June & 17 & $4(23)$ & 4 & 0 & $4(23)$ & $4(23)$ & $8(47)$ \\
\hline Total & 2.33 & $74(32)$ & $11(5)$ & $7(3)$ & $81(35)$ & $18(8)$ & $92(39)$ \\
\hline
\end{tabular}

* Other etiologic agents were not investigated. 
adults is high, ${ }^{25}$ compared with those in industrialized countries. ${ }^{10,11}$ Differences are explained by greater opportunities for infection in developing countries, favored by poor sanitation and contact with diartheic patients and animals. By contrast, infection tends to be food-borne in industrialized nations. In Costa Rica, Campylobacter frequency rates oscillated around $8 \%$. This 7-month survey, and an ongoing long-term field study in Puriscal, ${ }^{\text {ts }}$ rank Campylobacter as second or third in importance as an etiologically associated agent of diarrhea.

Parasites did not appear as important agents of acute diarrhea, but they may be relevant in chronic situations. Parasitic forms are washed away during bouts of diarrhea, interfering with proper diagnosis. The present survey, however, is not conclusive with regard to parasites, as prospective analysis of field data showed that they may appear shortly before or shortly after the onset of the episode. ${ }^{27}$

Significant differences were observed between hospitalized diarrheic and non-diarrheic patients regarding excretion of all five agents studied. There were few symptomless cases with bacteria and viral agents, indicating the high pathogenic potential of such agents. Infections in the non-diarrheic controls probably were of nosocomial origin. One control patient excreted both ST- and LT-producing ETEC and another was simultaneously infected with rotavirus and Shigella. This latter patient passed normal stools during his 6-day stay in the hospital. Rotavirus excretion was found in only $0.9 \%$ of control subjects, a much lower percentage than described elsewhere. ${ }^{20,24,28}$

Clinical features of specific diarrheas were similar to those described by other workers. 12. 17, 20.30 The rate of dehydration was relatively lower than described for poor rural children, ${ }^{29}$ and may be accounted for by the adequate nutritional state of the Costa Rican population ${ }^{1}$ and its greater awareness of the seriousness of the disease, which results in earlier medical attention. Except for the large number of inflammatory and red blood cells in shigellosis, symptomatology and clinical characteristics of stools were similar for all specific diarrheas.

Age distribution of "pure" single infections showed that most of them were in 3- to 8-monthold infants. It has been recognized that rotavirus in children under 6 months of age generally results in either asymptomatic or mild clinical excretion of virions, whether children are breast-fed or not. ${ }^{31,} 32$ Asymptomatic endemic infection of normal neonates has been documented in England and Australia, ${ }^{302}$ a phenomenon seemingly independent of type of feeding and antibody titer in human milk. "On the other hand, infection of high risk neonates not protected by human milk has been associated with outbreaks of severe diarthea and necrotizing enterocolitis. ${ }^{\mathrm{MH}, 35}$

Examination of feces or rectal swabs in the first four days of the disease gave more than $80 \%$ of the total rotavirus and ETEC diagnoses, indicating the need for investigation early in the course of the disease.

Rotaviruses exhibit a seasonal variation in countries with temperate climates, with rates reaching 80 to $95 \%$ during winter months. ${ }^{12,36,37}$ In Costa Rica, frequency rates of 50-90\% were seen in the cooler and dry months of November through January. ${ }^{13,38,39}$ Furthermore, whereas in temperate settings rotaviruses are hardly detected during non-epidemic months, in Costa Rica, as in Venezuela and Bangladesh, ${ }^{20.21}$ they remained endemic throughout the study period with an overall rate of $45 \%$. While the highest relative frequency of rotaviruses was in the dry and cooler months, no significant correlation was observed with temperature. However, a significant negative correlation between rainfall and relative humidity and rotavirus frequency rate was observed, suggesting that the dry and cool season might favor rotavirus infection. In this season Costa Ricans spend more time in the home and due to low temperatures in the Intermountain Central Valley they may use less water for personal hygiene and other purposes. The largest rotavirus outbreak was recorded in December 1976-February 1977. The year 1976 was characterized by epidemics in temperate climates. ${ }^{12,36,37}$ The endemicity and epidemicity of rotavirus diarrhea appear to have decreased since that extensive outbreak.

With regard to control and prevention, an oral rehydration scheme has been routinely operating at the National Children's Hospital since 1978," with a reduction of more than $90 \%$ in lethality from the pre-oral rehydration level. ${ }^{41}$ The same oral rehydration scheme was successfully used to treat neonates, ${ }^{22}$ even when hypernatremia or hyponatremia were present. Oral rehydration sachets with instructions are distributed to about 200,000 primarily rural families each year, for home oral rehydration. ${ }^{3}$ An emphasis in promo- 
tion of breast-feeding collateral with an understanding of the epidemiology of diarrheal disease, and with holistic interventions, have drastically reduced diarrhea and infant mortality in a pilot study area. ${ }^{\text {g7, }}$,4

\section{ACKNOWLEDGMENTS}

We thank Drs. R. G. Wyatt, R. H. Yolken, T. H. Flewett, R. F. Bishop and A. Z. Kapikian, for technical information and materials provided during the study. Drs. M. E. Peñaranda and $\mathbf{L}$. Reyes of INISA helped in the laboratory in the first two years of the study. Ms. J. León collected fecal specimens and Mr. V. J. Solís processed data for computer display. This study was financed in part by the University of Costa Rica Vice-Presidency for Research, the Consejo Nacional de Investigaciones Científicas y Tecnológicas and USAID Loan 515-T-026.

\section{REFERENCES}

1. Mata, L. J., and Mohs, E., 1978. As seen from national levels: Developing world. Pages 254-264 in S. Margen and R. A. Ogra, eds., Progness in Human Nutrition, vol. 2. Ari Pub. Co. Inc. Westport, Conn.

2. Villegas, H., and Osuna, J., 1979. Extensión de los servicios de salud de Costa Rica. Pages 168183 in Condiciones de Salud del Niño en las Américas. PAHO Sci. Pub. No. 381.

3. Mata, L., 1981 . Epidemiologic perspective of diartheal disease in Costa Rica and current efforts in control, prevention and research. Rev. Lat-amer. Microbiol., 23: 109-119.

4. Mata, L. J., Gangarosa, E. J., Cáceres, A., Perera, D. R., and Mejicanos, M. L., 1970. Epidemic Shiga bacillus dysentery in Central America. 1. Etiologic investigations in Guatemala, 1969. J. Infect. Dis, 122: 170-180.

5. Edwards, P. R, and Ewing, W. H., 1972. Identification of Enterobacteriaceac. 3rd ed. Burgess Pub. Co., Minneapolis, Minnesota.

6. Evans, D. J., and Evans, D. G., 1977. Direct serological assay for the beat-labile enterotoxin of Escherichia coli ising passive immune hemolysis. Infect. Immun., 16: 604-609.

7. Yolken, R. H., Greenberg, H. B., Merson, M. H., Sack, R. B., and Kapikian, A. Z., 1977. Enzyme-linked immunosorbent assay for detection of Escherichio coli heat-labile enterotoxin. $J$. Clin. Microbiol., 6: $439-444$.

8. Simhon, A., Reyes, L., Padilla, R., and Mata, L., 1981. Ensayo inmunosorbente-enzima conjugada (ELISA) e inmunohemólisis pasiva (IHP) de la toxina lábil de Eseherichia coli. Rev. Lat-amer. Microbiol., 23: 193-197.

9. Stavric, S., and Jeffrey, D., 1977. A modified bioassay for heat-stable Escherichic coli enterotoxin. Can. J. Microbiol., 23: 331-336.

10. Butzler, J. P., 1981. Compylobacter enteritis. Pages 63-72 in T. Holme, J. Holmgren, M. H. Merson, and R. Mollby, eds., Acute Enteric Infections in Children. New Prospects for Treatment and Prevention. Flsevier/North Holland.

11. Skirrow, M. B., and Benjamin, J., 1980. '1001' campylobacters: cultural characteristics of intestinal campylobacters from man and animals. $J$. Hyg. (Cambridge), 85: 427-442.

12. Flewett, T. H., Bryden, A. S., and Davies, H., 1974. Diagnostic electron microscopy of faeces. I. The viral flora of the faeces as seen by electron microscopy. J. Clin. Pathol., 27: 603-614.

13. Mata, L., Lizano, C., Hernández, F., Mohs, E., Herrero, L., Peñaranda, M. E., Gamboa, F., and León, J., 1977. Agentes infecciosos en la diarrea del niño hospitalizado en Costa Rica. Bol. Hosp. Inf. Méx., 34: 955-969.

14. Yolken, R. H., Kim, H. W., Clem, T., Wyatt, R. G., Kalica, A. R., Chanock, R. M., and Kapikian, A. Z., 1977. Enzyme-linked immunosorbent assay (EI.ISA) for detection of human reovirus-like agent of infantile gastroenteritis. Lancel, 2: 263-266.

15. Yotken, R. H., Wyatt, R. G., and Kapikian, A. Z., 1977. ELISA for rotavirus. Lancet, 2: 818 .

16. Simhon, A., Amato, S., Hernández, F., Yolken, R. H., and Mata, 1., 1979. Diagnóstico de rotavirus por microscopía electrónica y el ensayo inmunosorbente enzima conjugada (ELISA). Bol. Ofic. Sanit. Panam., 86: 391-397.

17. Kapikian, A. Z., Yolken, R. H., Greenber, H. B., Wyatt, R. G., Kalica, A. R., Chanock, R. M., and $\mathbf{K i m}, \mathbf{H}$. W., 1979. Gastroenteritis viruses. Pages 927-995 in E. H. Lennette and N. J. Schmidt, eds., Diagnostic Procedures for Viral, Ricketisial and Chlomydial Infections, 5th ed., American Public Health Association, Washington, D.C.

18. Ritchie, L. S., 1948. An ether sedimentation technique for routine stool examinations. $B u l l . U, S$. Army Med. Dept, 8: 326.

19. W.H.O. Scientific Working Group., 1980. Rotavirus and other viral diarrhoeas. Bull. W.H.O., 58: 183-198.

20. De Torres, B. V., Mazzali de Ija, R., and Esparza, J., 1978. Epidemiological aspects of rotavirus infection in hospitalized Venezuelan children with gastroenteritis. Am. J. Trop. Med. Hyg., 27: 567572.

21. Black, R. E., Merson, M. H., Rahman, A. S. M. M., Yanus, M., Alim, A. R. M. A., Ruq, I. Yolken, R. H, and Curlin, G. T., 1980. A two year study of bacterial, viral, and parasitic agents associated with diarhea in rural Bangladesh. $J$. Infect. Dis., 142: 660-664.

22. Espeja, R. T., Caldeión, E., González, N., Salomon, A., Martuscelli, A., and Romero, P., 1978. Rotavinis eastroenteritis in bospitalized infants and young children in Mexico City. Rev. Lat amer. Microbiol., 20: 239-246.

23. Evans, D. G., Olarte, J., DaPont, H. L., Evans, 
D. J., Galindo, A., Portnoy- B. L., and Conklin, R. H., 1977. Enteropathugens associated with pediatric diarthea in Mexice City. J. Pediat., 01: $55-68$.

24. Pickering, L. K., Evans, D. J., Muñoz, O., DuPont, H. L., Coello-Ramirez, P., Vollet, J. J., Conklin, R. H., Olarte, J., and Kohl, S., 1978. Prospective study of enteropathogens in children with diarrhea in Houston and Mexico. $J . P e$ diat., 93: 383-388.

25. Bokkenheuser, V. D., Richardson, N. J., Bryner, J. H., Roux, D. J., Schutte, A. B., Koorhof, H. J., Freiman, I., and Hartman, E., 1979. Detection of enteric campylobacteriosis in children. $J$. Clin. Microbiol., 9: 227-232.

26. Vives, M., Jiménez, P., and Mata, L., 1982. Campylobacter fetus jejuni en una población rural en transición, Puriscal, Costa Rica. Rev. Med. Hosp. Nac. Niños (Costa Rica). (In press.)

27. Mata, L., Jiménez, P., Allen, M. A., Vargas, W., García, M. E., Urrutia, J. J., and Wyatt, R. G., 1981. Diarrhea and malnutrition: breast-feeding intervention in a transitional population. Pages 233-25 1 in T. Holme, J. Holmgren, M. H. Merson, and $R$. Mollby, eds., Acute Enteric Infections in Children. New Prospects for Treatment and Prevention. Elsevier/North Holland.

28. Stintzing, G., Tufvesson, B., Habte, D., Back, E., Johnsson, T., and Wadstrom, T., 1977. Aetiology of acute diarrheal disease in infancy and childhood, during the peak season, Addis Ababa 1977: a preliminary report. Ethiop. Med. J., 15: 141-145.

29. Wyatt, R. G., Yolken, R. H., Urrutia, J. J., Mata, L., Greenberg, H. B., Chanock, R. M., and Kapikian, A. Z., 1979. Diarrhea associated with rotavitus in rural Guatemala: a longitudinal study of 24 infants and young children. $A \mathrm{~m}$. J. Trop. Med, Hyg., 28: 325-328.

30. DuPont, H. L., and Pickering, L. K., 1980. Infections of the Gastrointestinal Tract. Microbiology, Pathophysiology, and Clinical Features. Plenum, New York, 273 pp.

31. Totterdell, B. M., Chrystie, I. L, McLeod, J., and Banatvala, J. E., 1981, Role of breast milk antibodies in protection against rotavirus infection. Abstracts 5th International Congress of Virology, Strasbourg, W16/07.

32. Gurwith, M., Wenman, W., Hinde, D., Feltham, S., and Greenberg, H., 1981. A prospective study of rotavirus infection in infants and young children. J. Infect. Dis., 144: 218-224.

33. Chrystie, I. L., Totterdell, B. M., and Banatvala,
J. E., 1978. Asymptomatic endemic rotavirus infections in the newborn. Lancet, 1: 1176-1178.

34. Bishop, R. F., Cameron, D. J. S., Veenstra, A. A., and Barnes, G. L., 1979. Diarrhea and rotavirus infection associated with different regimens for postnatal care of newborn babies. J. Clin. Microbiol., 9: 525-529.

35. Odio, C., Hernández, F., Ruiz, M. A., Padilla, R., and Mohs, E., 1980. Rotavirus en un servicio de neonatología. Descripción de una epidemia. Rev. Méd. Hosp. Nac. Niños (Costa Rica), 15: 159-172.

36. Kapikian, A. Z., Kim, H. W., Wyatt, R. G., Cline, W. L., Arrobio, J. D., Brandt, C. D., Rodriguez, W. J., Sack, D. A., Chanock, R. M., and Parrott, R. H., 1976. Human reovirus-like agent as the major pathogen associated with "winter" gastroenteritis in hospitalized infants and young children. N. Engl. J. Med., 204: 965-972.

37. Konno, T., Suzuki, H., Imai, A., Dutsuzawa, T., Ishida, N., Katsushima, N., Sakamoto, $\mathbf{M}$, $\mathbf{K j}$ taoka, S., Tsuboi, R., and Adachi, M., 1978. A long-term survey of rotavirus infection in Japanese children with acute gastroenteritis. $J . I n$ fect. Dis., 138: 569-576.

38. Hernández, F., Mata, L. J., Lizano, C., and Mohs, E., 1977. Prevalencia de rotavirus y descripción de una epidemia de diarrea por este agente en Costa Rica. Acte Méd. Costamicense, 20: 297304.

39. Hieber, J. P., Shelton, S., Nelson, J. D., León, J. and Mohs, E., 1978. Comparison of human rotavirus disease in tropical and temperate settings. Am. J. Dis. Child., 132: 853-858.

40. Nalin, D. R, Levine, M. M., Mata, L., de Céspedes, C., Vargas, W., Lizano, C., Loría, A. R., Simhon, A., and Mohs, E., 1979. Oral rebydration and maintenance of children with rotavirus and bacterial diarrhoeas. Bull.W.H.O., 57; 453-459.

41. Odio, C., and Mohs, E., 1980. Características actuales de la letalidad por diarrea. Rev. Méd. Hosp. Nac. Niños (Costa Rica), 15: 181-187.

42. Pizarro, D., Posada, G., Mata, L., Nalin, D., and Mohs, E., 1979. Oral rehydration of neonates with dehydration diarrhoeas. Lancet, 2: 12091210.

43. Mata, L., Jiménez, P., García, M. E., Castro, B., Vives, M., Allen, M. A., and Sánchez, F., 1982. Estudio de Puriscal. IX. Estado nutricional y supervivencia del nin̄o. Observación prospectiva, 1979-1982. Rev. Med. Hosp. Nac. Niños (Costa Rica). (In press.) 